\title{
ANALISIS GAYA BAHASA DAN NILAI MORAL PADA IKLAN LAYANAN MASYARAKAT DI SEPANJANG JALAN SOLO-NGAWI
}

\author{
Language Style Analisis and Moral Values in Community Service Ads \\ Along Solo-Ngawi Street
}

\author{
Aulia Normalita, Dian Uswatun Hasanah \\ Institut Agama Islam Negeri Surakarta \\ aulianormalita277@gmail.com
}

(Masuk: 15 September 2019, diterima: 19 Maret 2020)

\begin{abstract}
Abstrak
Peneliti akan membahas kreativitas pembuat iklan yang memproduksi iklan dengan gaya yang menarik dari segi kebahasaan, sehingga dari iklan-iklan tersebut mampu memunculkan gaya bahasa yang tidak hanya unik namun juga mengandung nilai moral yang dapat mendidik masyarakat. Penelitian ini bertujuan untuk mendeskripsikan jenis-jenis gaya bahasa dan nilai moral pada iklan layanan masyarakat di sepanjang jalan Solo-Ngawi. Jenis penelitian adalah deskriptif kualitatif. Teknik pengumpulan data menggunakan teknik analisis dokumen berupa gambar, foto dan tulisan dari iklaniklan yang ditemukan. Keabsahan data menggunakan teknik triangulasi teori dengan cara menyocokkan beberapa teori dari data yang ada. Hasil penyocokkan data ditemukan sesuai dengan teori yang dikemukakan oleh Ratna (2013). Hasil penelitian ditemukan berupa gaya bahasa penegasan yang berjumlah dua puluh data, sindiran berjumlah enam data sedangkan data yang mengandung nilai moral kepedulian sosial berjumlah tujuh belas data. Gaya bahasa dan nilai moral pada iklan layanan masyarakat, dapat menjadi pengingat dan pelajaran bagi para pengguna lalu lintas dan masyarakat dari iklan yang ditemui.
\end{abstract}

Kata kunci: gaya bahasa, nilai moral, iklan layanan masyarakat.

\begin{abstract}
This study discusses the creativity of ad builders who produce ads in a style that is appealing in terms of the language, so that from those ads is able to bring out a style that is not only unique but also contains moral values that can educate Community. The research aims to describe the kinds of language styles and moral values in the public service advertisement along Solo-Ngawi road. This type of research is qualitative descriptive. Data collection techniques using document analysis techniques in the form of images, photographs and writings of advertisements found. The validity of the data uses theoretical triangulation techniques by matching some theories from existing data. Data matching results are found in accordance with Ratna's theory. The results of the study were found an affirmation style of twenty data. Seventeen data is the moral value of ad type traffic. The style of language and moral value of community service ads, can be a reminder and a lesson for traffic and community users of the advertisements found.
\end{abstract}

Keywords: language style, moral value, advertising community service 


\section{PENDAHULUAN}

Bahasa, komunikasi, dan kehidupan merupakan satu kesatuan yang tidak dapat dipisahkan. Melalui bahasa, orang akan mudah memahami apa yang ingin disampaikan. Bahasa sendiri bersifat dinamis, yang berarti setiap saat akan mengalami perubahan dan perkembangan seiring gerak dan kegiatan sepanjang peradaban manusia. Salah satu fungsi bahasa ialah sebagai alat komunikasi untuk menyampaikan pesan. Penyampaian pesan dari pembicara atau penulis kepada pendengar maupun pembaca. Baik secara tersirat maupun tersurat.

Nasucha dkk. (2012:14) menjelaskan ragam bahasa ditinjau dari media dibagi menjadi dua. Pertama media lisan, kedua media tulis. Ragam bahasa lisan ialah bahasa yang bersifat produktif, yang dapat diucapkan oleh penutur dan dapat diterima secara langsung oleh pendengar. Kedua ialah ragam bahasa tulis. Bahasa tulis ialah bahasa yang bersifat reseptif atau menerima. Ragammedia tulis tidak melihat situasi pemakaian. Namun sangat memperhatikan kecermatan dan ketepatan di dalam pemilihan kata, struktur kalimat, serta kelengkapan unsur-unsur bahasa di dalam struktur kalimat.

Teeuw (2015:28) berpendapat bahwa teks tulis memungkinkan pembaca tidak memahami situasi pengarang, situasi sosial. Pembaca hanya dapat memahami informasi yang dibacanya. Teks tulis memiliki ruang lingkup yang lebih besar dan luas daripada lisan. Contoh teks tulis misalnya iklan layanan masyarakat yang ditujukan oleh khalayak umum. Adapun tujuan dari iklan layanan masyarakat ialah untuk mengingatkan masyarakat terhadap suatu aturan, menyampaikan informasi kepada masyarakat serta menambah kesadaran dan sikap terhadap suatu hal. Penelitian ini membahas kreativitas pembuat iklan yang memproduksi iklan dengan gaya yang menarik dari segi kebahasaan sehingga dari iklan-iklan tersebut mampu memunculkan gaya bahasa yang tidak hanya unik, namun juga mengandung nilai moral yang dapat mendidik masyarakat. Penelitian ini bertujuan untuk mendeskripsikan jenis-jenis gaya bahasa dan nilai moral pada iklan layanan masyarakat di sepanjang jalan Solo-Ngawi.

Keunikan yang ada pada iklan layanan masyarakat ialah penggunaan gaya bahasa dan nilai moral di dalamnya. Penelitian terdahulu sama halnya dengan penelitian (Inderasari dan Achsani, 2018), yakni penelitian gaya bahasa dan nilai moral pada lirik lagu genre dan koplo yang menunjukkan adanya gaya bahasa repetisi dan perbandingan pada lirik lagu tersebut serta dapat belajar dari nilai moral berupa menepati janji, hati-hati dalam perkataan, berbakti kepada orangtua, menghargai orang lain, selalu tegar dan ikhlas dalam menjalani takdir. Pesan moral tersebut dapat menjadikan seseorang menjadi pribadi yang lebih berhati-hati dalam bergaul dengan orang lain. Selain itu, (Hasanah, Achsani, dan Aziz, 2019) mengkaji tentang gaya bahasa repetisi dan pertentangan pada puisi karya Fadli Zon. Hasil penelitian tersebut terdapat gaya bahasa yang didominasi oleh gaya bahasa repetisi dan pertentangan, puisi-puisi tersebut diciptakan sebagai bentuk kritikan terhadap pemerintah, puisi tersebut sebagai ajang untuk mengutarakan gagasan yang dimiliki pencipta melalui puisi.

Ratna (2013:3) mendefinisikan stilistika atau stylistic adalah ilmu tentang gaya, sedangkan stil atau style ialah cara-cara yang khas, bagaimana segala sesuatu diungkapkan dengan cara tertentu, sehingga tujuan yang dimaksud dapat tercapai secara maksimal. (Munir dkk, 2013:3) memaparkan gaya sebagai perwujudan gambaran, ide, gagasan untuk membuahkan efek tertentu sebagai ungkapan dari seorang penulis. Oleh sebab itu, pentingnya penggunaan gaya bahasa dalam iklan layanan masyarakat akan sangat membantu untuk mengajak, mengingatkan, memengaruhi, khalayak umum terhadap apa yang ingin disampaikan oleh komunikator.

Adapun pengertian nilai moral ialah hubungan dengan masyarakat yang menyangkut 
hubungan antara manusia dalam kehidupan sosial. Moral berurusan dengan permasalahan baik dan buruk, namun hal tersebut selalu dikonotasikan dengan sesuatu yang baik. Hal tersebut senantiasa berkaitan dengan berbagai hal yang berkonotasi positif, bermanfat bagi kehidupan, dan mendidik. Moral, amanat, atau messages dapat dipahami sebagai sesuatu yang ingin disampaikan kepada pembaca (Salfia, 2015:7). Amanat bertujuan untuk menambah pengetahuan dan menumbuhkan kesadaran sikap dan perubahan perilaku masyarakat terhadap masalah yang disampaikan serta mendapat citra baik di benak masyarakat. Abdul dan Yusuf(2010: xvi) juga menjelaskan mengenai moral dalam dimensi kemanusiaan (insaniyah) juga dijelaskan hubungan individu dengan sesama manusia, yang di dalamnya ditanamkan nilai-nilai kemanusiaan yang universal, seperti saling tolong menolong, menghormati, simpati, empati, memiliki tanggung jawab sosial, kepedulian sosial, dan kepekaan sosial.

Iklan layanan masyarakat sendiri ialah iklan menurut Neonisa (2011:1449) sebagai iklan yang digunakan untuk menyampaikan informasi, mengajak, atau mendidik masyarakat di mana tujuan akhir bukan untuk mendapatkan keuntungan ekonomi, melainkan keuntungan sosial. Keuntungan sosial yang dimaksud adalah munculnya penambahan pengetahuan, kesadaran sikap dan perubahan perilaku masyarakat terhadap masalah yang diiklan, serta mendapatkan citra baik di mata masyarakat. Sama halnya dengan Pujiyanto (2013:11) mengatakan bahwa iklan layanan masyarakat adalah suatu proses penyampaian informasi yang bersifat persuasif atau mendidik khalayak melalui media periklanan.

Gaya bahasa ekslamasio adalah gaya bahasa yang menggunakan kata: wah, aduh, amboi, astaga, awas, dan sebagainya. Asonansi merupakan perulangan bunyi vokal. Aforimse, yang berarti memberikan pernyataan sebagai kebenaran umum atau kata-kata bijaksana. Adapun gaya bahasa tautotes yang terdapat memiliki arti perulangan dalam sebuah susunan kata atau kalimat. Pararelisme merupakan gaya bahasa yang memiliki arti kesejajaran atau kesetaraan kata-kata atau frasa, dengan fungsi yang masing-masing sama (Ratna, 2013).

Tautologi yaitu perulangan kata, kelompok kata, atau sinonimnya, yang kadangkadang tidak perlu. Mesodiplosis yang menggunakan perulangan di tengah baris. Selanjutnya gaya bahasa pararima ialah pengulangan bunyi konsonan. Gaya bahasa aferesis adalah gaya bahasa penegasan yang menghilangkan huruf atau suku kata di awal. Jenis gaya bahasa epifora atau epistrofa yaitu bentuk gaya bahasa yang di dalamnya terdapat perulangan kata di akhir kalimat secara berurutan. ironi memiliki arti sindiran halus. Majas metonimia adalah majas yang menggunakan suatu nama tetapi yang dimaksud adalah benda atau nama lain. Sarkasme ialah gaya bahasa yang berupa sindiran kasar. (Ratna, 2013).

Pada penelitian ini seluruh data yang diambil oleh peneliti bersumber di sepanjang jalan Solo-Ngawi. Peneliti melihat dan mengamati iklan-iklan yang berjejer di sepanjang jalan tersebut untuk dipilah dan digunakan sebagai data untuk kemudian diteliti. Semakin panjang jalan yang dilalui, maka akan semakin banyak data yang ditemukan di jalan tersebut.

\section{HASIL DAN PEMBAHASAN}

Berikut adalah pemaparan data yang ditemukan oleh peneliti di sepanjang jalan SoloNgawi, data-data tersebut beraneka ragam jenis gaya bahasa dan nilai moral. 


\begin{tabular}{|c|c|c|}
\hline Bentuk Gaya Bahasa & No & Data \\
\hline Ekslamasio & 1. & Awas!! Banyak tikungan tajam setajam silet \\
\hline Ekslamasio & 2. & Stop kekerasan terhadap perempuan dan anak \\
\hline Ekslamasio & 3. & $\begin{array}{l}\text { Ayo!!! } \\
\text { Budayakan Matikan Tv, Hp, Membaca Kitab Suci dan } \\
\text { Belajar Jam } 18.00 \text { sd } 20.00 \text { WIB. }\end{array}$ \\
\hline Ekslamasio & 4. & $\begin{array}{l}\text { Stop Pungli } \\
\text { Penerima dan Pemberi sama-sama melanggar hukum }\end{array}$ \\
\hline 1. GayshaBanika Penega & $\mathbf{a n}$ & $\begin{array}{l}\text { Awas...! } \\
\text { Hati-hati..! } \\
\text { Jalan Menanjak Tetap Fokus dan Jaga Jarak }\end{array}$ \\
\hline Ekslamasio & 6. & Awas! Daerah Rawan Kecelakaan \\
\hline Ekslamasio & 7. & $\begin{array}{l}\text { Ingin Tahu Mukjizat Al Quran?? } \\
\text { Ayo!!! Baca dengan Arti dan Maknanya. }\end{array}$ \\
\hline Pararelisme & 8. & Indahnya Sungai Tanpa Sampah dan Limbah \\
\hline Tautotes & 9. & $\begin{array}{l}\text { Sungai adalah CiptaanTuhan, } \\
\text { Jika Kita Menjaga Sungai, } \\
\text { Tuhan akan menjaga Kita }\end{array}$ \\
\hline Aforisme & 10. & Sungaimu Cerminan Kotamu \\
\hline Aforisme & 11. & Jaga Masa Depanmu, Katakan Tidak Pada Narkoba. \\
\hline Aforisme & 12. & $\begin{array}{l}\text { Ingin Tahu Mukjizat Al Quran?? } \\
\text { Ayo!!! Baca dengan Arti dan Maknanya. }\end{array}$ \\
\hline Tautologi & 13. & $\begin{array}{l}\text { Terorisme } \\
\text { Perusak Persatuan, Perdamaian, dan Peradaban }\end{array}$ \\
\hline Tautologi & 14. & $\begin{array}{l}\text { Sampah, Limbah, dan Kotoran Lainnya adalah Sumber } \\
\text { Penyakit, Dilarang Membuangnya ke Sungai. }\end{array}$ \\
\hline Asonansi & 15. & Hati-hati! Jalan Berlobang dan Bergelombang \\
\hline Asonansi & 16. & Becik ketitik olo ketoro kaline resik, ora marai memolo \\
\hline Mesodiplosis & 17. & $\begin{array}{l}\text { pilih helm yang standar, } \\
\text { Pakai helm yang benar, } \\
\text { Pasang gesper dagu sampai terdengar "Klik" }\end{array}$ \\
\hline Pararima & 18. & $\begin{array}{l}\text { Ajal Tidak Menunggu Taubatmu, } \\
\text { Yuk Tobat Sebelum Terlambat }\end{array}$ \\
\hline Aferesis & 19. & $\begin{array}{l}\text { Keselamatan Kerja Tak Akan Pernah Libur } \\
\text { Karena Bahaya Tak Mengenal Kata Cuti }\end{array}$ \\
\hline Epifora & 20. & $\begin{array}{l}\text { Kecelakaan Lalu Lintas } \\
\text { Selalu didahului pelanggaran Lalu Lintas }\end{array}$ \\
\hline
\end{tabular}

Data (1) Gaya bahasa tersebut adalah jenis gaya bahasa ekslamasio yang terdapat dalam kata awas yang menekankan pada kehati-hatian pada saat melewati tikungan, ditambah lagi dengan penggunaan dua tanda seru untuk menegaskan kata awas tersebut.

Data (2) Pada kata stop menunjukkan gaya bahasa ekslamasio karena masuk dalam kata penegasan untuk tidak melakukan kekerasan terhadap perempuan maupun anakanak. Sejauh ini seorang laki-laki masih mengasumsikan bahwa perempuan dan anakanak adalah sasaran empuk untuk tindakan kriminal maupun kekerasan, sebab pada dasarnya mereka masih menganggap perempuan dan anak adalah makhluk yang lemah. 
Data (3) gaya bahasa pada data di atas adaah ekslamasio. Sebab, dalam iklan di atas terdapat kata seru yang berupa kata ayo.

Data (4) data tersebut berupa gaya bahasa ekslamasio yang terdapat pada kata stop di awal kata pada iklan layanan masyarakat di atas. Kata stop menunjukkan kata imbauan.

Data (5) Iklan di atas terdapat dua gaya bahasa ekslamasio dan asonansi, yaitu jenis majas penegasan. Kata awas telah menunjukkan gaya bahasa ekslamasio. Tanda seru menunjukkan bahwa kata tersebut memberikan penegasan untuk tetap berwaspada dan hati-hati. Pada kata jalan menanjak tetap fokus dan jaga jarak tersebut berupa gaya bahasa asonansi sebab terdapat pengulangan bunyi vokal/a//a/ di awal dan akhir kalimat.

Data (6) Ekslamasio menempati gaya bahasa yang terdapat pada iklan layanan masyarakat tersebut. Jelas dengan adanya dua tanda seru yang menunjukkan gaya bahasa penegasan dengan jenis ekslamasio yang ditunjukkan dengan kata awas. Kalimat iklan tersebut menegaskan bahwa di daerah Sragen tepatnya sering terjadi kecelakaan sehingga beberapa iklan imbauan yang berupa penegasan bermunculan. Salah satunya adalah iklan layanan masyarakat seperti yang terdapat pada data enam ini.

Data (7) gaya bahasa ekslamasio yang berarti penggunaan kata seru, dapat berupa awas, stop, wah, astaga, ayo dan kata-kata yang menunjukkan sebuah seruan tentang suatu peristiwa. Kata ayo dalam iklan di atas menunjukkan adanya gaya bahasa ekslamasio ditambah dengan dua tanda seru yang mengartikan sebuah penegasan atau seruan agar tidak hanya membaca al quran tetapi juga membaca maknanya apabila ingin mengetahu mukjizat dari al quran sendiri.

Data (8) berupa gaya bahasa pararelisme yang terdapat pada kata sampah dan limbah yang sama-sama memiliki arti barang atau benda yang sudah tidak dipakai lagi. Kedua kata tersebut sejatinya memiliki makna yang hampir sama, yaitu sesuatu yang sudah bekas dan tidak dipakai lagi. Oleh sebab itu, iklan tersebut secara tersirat bermaksud untuk menegaskan kepada masyarakat agar tidak membuang apapun ke sungai baik berupa limbah atau sampah, karena hal tersebut dapat merugikan semua pihak.

Data (9) gaya bahasa tautotes yang terdapat pada iklan di atas, yang memiliki arti perulangan dalam sebuah susunan kata atau kalimat. Tautotes yang terdapat pada iklan di atas mengalami tiga perulangan kata, yaitu pada sungai, Tuhan, dan kita. Kata sungai mengalami pengulangan pada kalimat kedua, sedangkan kata Tuhan diulang pada kalimat ketiga kemudian kata kita dari kalimat kedua diulang pada kalimat ketiga. Hal ini yang menunjukkan bahwa perulangan tesebut termasuk dalam kategori gaya bahasa tautotes sebab beberapa kata yang tercantum diulang secara berturut-turut. Iklan di atas mengingatkan kepada kekuasaan Tuhan yang Maha Esa. Tuhan pengatur segala pun pemiliki segala. Apabila makhluk menjaga apa yang telah diberinya, maka tugas manusia hanya menjaganya. Apabila makhluk Tuhan telah menjaganya maka Tuhan pun akan ikut serta menjaga makhluknya.

Data (10) gaya bahasa Aforisme adalah pernyataan sebagai kebenaran umum atau katakata bijaksana. Iklan layanan masyarakat di atas yang menunjukkan gaya bahasa aforisme yang terdapat pada kata cerminan kotamu. Iklan di atas, menunjukkan penggunaan bahasa yang bijaksana dan bersifat membenarkan apa yang seharusnya dilakukan.

Data (11) gaya bahasa aforisme karena diketahui secara jelas bahwa iklan tersebut memiliki pernyataan yang benar bahwa semua orang tahu sejak dahulu sudah ada larangan keras untuk menjauhi obat-obatan terlarang seperti narkoba salah satunya. Pada iklan di atas, gaya bahasa yang terkandung berupa aforisme yaitu gaya bahasa jenis penegasan yang artinya pernyataan sebagai kebenaran umum atau mengandung kata-kata arif. Kalimat yang menunjukkan kearifan terdapat pada jaga masa depanmu. Kalimat tersebut 
menunjukkan kebijaksanaan dalam penyampaiannya. Kemudian dilanjut dengan katakan tidak pada narkoba yang menjadi anak kalimat.

Data (12) gaya bahasa aforisme dan gaya bahasa ekslamasio. Aforisme, yang berarti memberikan pernyataan sebagai kebenaran umum atau kata-kata bijaksana. Pada iklan tersebut menjelaskan apabila ingin mengetahui al quran secara lebih dalam, maka dianjurkan untuk membaca terjemah atau maknanya tidak hanya membaca arabnya.

Data (13) adalah tautologi, penggunaan istilah yang digunakan pada iklan tersebut memang secara kata memiliki kesamaan makna, kata pertama adalah persatuan. Pembaca sudah tahu bahwa apabila suatu kelompok atau suatu masyarakat sudah bersatu maka kedamaian dan peradaban akan terjalin dan tumbuh di dalamnya. Kemudian dilanjut pada kata kedua yaitu perdamaian, suatu bangsa akan mencapai perdamaian apabila mereka telah bersatu. Jadi kedua kata yang digunakan setelah persatuan yaitu peradaban, lebih meluas sebab peradaban lebih kompleks dari sekadar persatuan, dan perdamaian. Namun ketiga kata yang digunakan memiliki persamaan makna yaitu sama-sama menjaga keutuhan dan perdamaian satu sama lain.

Data (14) tautologi adalah gaya bahasa perulangan, selain tautologi terdapat gaya bahasa polisidenton. Gaya bahasa perulangan dengan cara mengulang kata, kelompok kata, atau sinonim yang terkadang tidak begitu perlu dimunculkan. Gaya bahasa tautologi di atas, ditandai dengan munculnya kata sampah, limbah, dan kotoran bahwa ketiga unsur tersebut memiliki persamaan kata. Pembaca akan memahami tanpa perlu diberi tahu bahwa sampah, kotoran dan lain-lain akan mengakibatkan penyakit apabila dibuang ke sungai. Adapun jenis gaya bahasa polisidenton tersebut masuk ke dalam jenis gaya bahasa penegasan. Pada kata dan yang menyebutkan beberapa jenis sampah, kata dan tersebut masuk dalam kategori gaya bahasa jenis polisidenton yang menggunakan kata hubung di dalamnya.

Data (15) gaya bahasa asonansi, perulangan bunyi vokal memiliki arti repitisi, sedangkan perulangan bunyi konsonan terdapat pada awal dan akhir dalam kata-kata tertentu. Iklan layanan masyarakat di atas memilki dua jenis gaya bahasa, asonansi dan pararima. Pengulangan bunyi vokal atau asonansi terdapat terdapat pada vokal /a/ dan /a/ pada kata berlobang dan bergelombang. Penggunaan gaya bahasa asonansi tersebut menegaskan kepada pengguna jalan untuk berhati-hati karena kondisi jalan yang berlobang dan bergelombang. Maka, selain menegaskan melalui kata berlobang dan bergelombang, komunikator juga menambahkan tanda seru (!) setelah kata hati-hati sebagai wujud penegasan untuk para pengemudi. Kemudian untuk bunyi konsonan kata tersebut ada pada/ng/ dan/ng/ di awal dan akhir kalimat pada kata tertentu. Sama halnya dengan bunyi vokal, bunyi konsonan terdapat pada kata berlobang dan bergelombang.

Data (16) Gaya bahasa asonansi. Pada kalimat iklan di atas adalah pengulangan bunyi vokal /i/ dan /o/ yang terdapat pada kata ketitik dan resik, ketoro dan memolo. Maksud dari peribahasa jawa pada kalimat pertama iklan di atas adalah sesuatu yang baik apabila ditutup-tutupi maka lambat laun akan muncul juga, dan sepandai-pandainya menutupi kejelekan pasti akan terlihat. Kemudian untuk kalimat yang kedua, ialah apabila sungai bersih maka tidak akan terjadi bencana seperti banjir, dan air sungai meluap akibat sampah-sampah yang ada.

Data (17) gaya bahasa mesodiplosis yang menggunakan perulangan di tengah baris. Perulangan kata di atas terdapat pada kata helm yang diulang sebanyak dua kali pada masing-masing kalimat. Tujuan utama menggunakana helm dan memasang gesper tidak lain adalah untuk menjaga keselamatan para pengguna motor sendiri. Oleh sebab itu, iklan layanan masyarakat di atas memberikan 
arahan terhadap masyarakat utamanya pengguna sepeda motor agar pemakaian helm sesuai dengan prosedur yang dituliskan, yakni memakai sampai gesper terdengar bunyi klik, maka helm yang dipakai dapat dikatakan aman.

Data (18) gaya bahasa pararima, satu keunikan bahasa yang digunakan oleh komunikator pada iklan layanan masyarakat ialah penyamaan bunyi dari kata yang ditulis. Perulangan konsonan pada iklan di atas yang pertama terdapat pada kalimat pertama yaitu menunggu taubatmu dan kalimat kedua tobat sebelum terlambat pengulangan konsonan tersebut diulang secara bertahap pada dua kalimat di atas. Tertera pada konsonan/u/ pada kalimat utama dan /a/ pada kalimat kedua, sehingga memunculkan irama yang pas ketika diucapkan dan terlihat lebih kreatif dalam menampilkan iklan. Iklan di atas termasuk jenis gaya bahasa pararima yang merupakan gaya bahasa dengan menggunakan perulangan bunyi konsonan di awal dan akhir pada kata-kata tertentu.

Data (19) adalah gaya bahasa aferesis yang menghilangkan huruf atau suku kata di awal. Pada iklan di atas, terdapat dua penghilangan suku kata di awal yaitu pada kata tak akan pernah libur yang hanya ditulis tak padahal apabila ditulis sesuai dengan kaidah Bahasa Indonesia yang benar tulisan tersebut kurang lengkap, seharusnya ditulis dengan kata (tidak). Namun pada sudut pandang lain, kata tak di atas memunculkan suatu majas yaitu majas aferesis. Pengulangan terjadi pada kalimat selanjutnya yaitu pada kalimat tak mengenal kata cuti yang hanya ditulis dengan suku kata tak yang seharusnya (tidak). Telah menghilangkan suku kata di beberapa kata pada iklan tersebut.

Data (20) gaya bahasa epifora, kecelakaan terjadi tidak melulu tentang jalan yang berlubang, atau rambu-rambu yang sedang rusak. Namun sebab lain dari seringnya terjadi kecelakaan ialah dari pihak pengendara sendiri, yaitu sering melanggar lalu lintas. Gaya bahasa yang menunjukkan epifora pada iklan tersebut terdapat pada kata lalu lintas karena pada kalimat pertama dicantumkan lalu lintas kemudian diulang pada kalimat kedua yaitu lalu lintas dengan cara menempatkan keduanya di akhir kalimat. Kedua kata tersebut membuktikan bahwa gaya bahasa epifora terdapat pada iklan layanan masyarakat di atas.

\section{Gaya Bahasa Sindiran}

\begin{tabular}{|c|c|l|}
\hline Bentuk Gaya Bahasa & No & \multicolumn{1}{|c|}{ Data } \\
\hline Ironi & 1. & Jangan Ikuti Jejak Saya \\
\hline Ironi & 2. & $\begin{array}{l}\text { Jangan Anda Jadi korban Berikutnya } \\
\text { Waspadalah }\end{array}$ \\
\hline Ironi & 3. & Mas Bro, Kalau Ngantuk Istirahat yaa.. \\
\hline Ironi & 4. & $\begin{array}{l}\text { Dilarang ngebut.. } \\
\text { Penggali kubur sudah pada lebaran }\end{array}$ \\
\hline Ironi & 5. & $\begin{array}{l}\text { LGBT } \\
\text { Lagi nyetir } \\
\text { Gak } \\
\text { Boleh } \\
\text { Telp }\end{array}$ \\
\hline Sarkasme & 6. & Jangan Kecelakaan di sini Rumah Sakit Jauh \\
\hline
\end{tabular}


Data (1) majas ironi, yaitu sindiran yang diperhalus memunculkan kalimat jangan ikuti jejak saya pada iklan di atas. Penggunaan bahasa formal yang benar memunculkan persepsi bahwa ungkapan melalui tulisan iklan tersebut terlihat begitu sopan. Makna dari kalimat jangan ikuti jejak saya mengartikan untuk tidak ikut terjerumus pada hal-hal yang tidak diinginkan. Misalnya, disebabkan ugalugalan yang berakibat kecelakaan, tidak mematuhi lalu lintas yang mengakibatkan kemacetan dan lain sebagainya.

Data (2) ironi, oleh sebab itu kalimat yang tertera pada iklan layanan masyarakat tersebut menggunakan pilihan kata yang lebih sopan seperti pada kata Anda, dan korban dan tetap diberi anjuran agar tetap waspada saat melintas di jalan tersebut. Meskipun di dalam tulisan tersebut diberi gambar tengkorak sebagai simbol kematian, namun komunikator tetap menggunakan kata-kata yang sopan dan bijak.

Data (3) jenis gaya bahasa ironi, artinya bahasa yang digunakan tidak sekasar majas sarkasme. Bahasa pada iklan layanan mayarakat di atas menunjukkan bahasa yang damai dan tidak menggertak pembaca, dalam hal ini bahasa yang digunakan oleh komunikator terkesan lebih santai dan lebih akrab dengan adanya kata mas bro. Ungakapan mas bro yang disertakan pada kalimat tersebut membuat pembaca seolah-olah diingatkan dengan kata teman sendiri, kemudian diperhalus kembali dengan kata istirahat yaa.. yang seolah-olah mengajak dengan cara yang baik dan sopan.

Data (4) gaya bahasa ironi adalah majas sindiran yang menggunakan bahasa atau kalimat diperhalus. Majas ironi selaras dengan isi iklan di atas, sedikit menyidir namun juga mengandung humor di dalamnya. Iklan tersebut berisi sindiran yang berupa dilarang ngebut, sebab penggali kubur telah pulang kampung untuk lebaran.
Data (5) Gaya bahasa pertama yaitu majas metonimia kedua adalah majas sindiran. Pada iklan tersebut menggunakan nama lain yang menarik yaitu LGBT. Pada umumnya masyarakat yang membaca tentu akan berpikir bahwa LGBT adalah Lesbian, Gay, Biseksual, dan Transgender. Namun yang dimaksud LGBT versi komunikator adalah Lagi nyetir Gak Boleh Telp. Hal ini menunjukkan bahwa iklan tersebut mengandung gaya bahasa metonimia, yang bermakna menggunakan suatu nama, tetapi dimaksudkan atau diartikan sebagai sesuatu yang lain. Kedua adalah majas sindiran, majas sindiran ini berbentuk majas ironi yaitu majas yang berupa sindiran halus. Kalimat iklan tersebut secara sinis menekankan bahawa orang yang sedang nyetir tidak boleh menelfon atau sekadar mengangkat telfon. Tidak lain karena hal tersebut dapat membahayakan dirinya sendiri maupun pengguna jalan yang lain.

Data (6) Bentuk gaya bahasa sarkasme. Hal tersebut dapat dilihat dari kalimat yang ditulis komunikator bahwa ada unsur sinis yang dimaksudkan, yaitu larangan untuk kecelakaan di area Ngawi karena jauh dari rumah sakit. Sarkasme pada majas atau gaya bahasa memang terkenal dengan ucapannya yang pedas tanpa memedulikan perasaan orang yang membaca.

Posisi gaya bahasa sindiran yang berupa ironi maupun sarkasme secara tersirat atau tersurat menegaskan kepada pengguna jalan untuk senantiasa mematuhi dan memperhatikan keselamatan mereka. Melalui iklan yang dipasang, hal tersebut sebagai wujud kepedulian komunikator untuk mengingatkan kepada pengguna lalu lintas. Adapun peringatanperingatan secara gamblang yang ditujukan kepada pengguna jalan kemudian tidak dipatuhi dan diindahkan, maka bukan salah oknum manampun apabila suatu waktu terjadi kecelakaan. Sebab semuanya kembali kepada kesadaran masing-masing. 


\section{Nilai Moral Kepedulian Sosial}

\begin{tabular}{|c|c|c|}
\hline Bentuk Nilai Moral & No. & Data \\
\hline Kepedulian sosial & 1. & Awas!! Banyak tikungan tajam setajam silet \\
\hline Kepedulian sosial & 2. & $\begin{array}{l}\text { Ajal Tidak Menunggu Taubatmu, } \\
\text { Yuk Tobat Sebelum Terlambat }\end{array}$ \\
\hline Kepedulian sosial & 3. & $\begin{array}{l}\text { Keselamatan Kerja Tak Akan Pernah Libur } \\
\text { Karena Bahaya Tak Mengenal Kata Cuti }\end{array}$ \\
\hline Kepedulian sosial & 4. & Jangan Ikuti Jejak Saya \\
\hline Kepedulian sosial & 5. & Hati-hati! Jalan Berlobang dan Bergelombang \\
\hline Kepedulian sosial & 6. & $\begin{array}{l}\text { Nganggo Helm..!! } \\
\text { Seng Lanang Tambah Ganteng } \\
\text { Seng Wedok Tambah Ayu }\end{array}$ \\
\hline Kepedulian sosial & 7. & $\begin{array}{l}\text { Awas...! } \\
\text { Hati-hati..! } \\
\text { Jalan Menanjak Tetap Fokus dan Jaga Jarak }\end{array}$ \\
\hline Kepedulian sosial & 8. & $\begin{array}{l}\text { Sampah, Limbah, dan Kotoran Lainnya adalah } \\
\text { Sumber Penyakit, } \\
\text { Dilarang Membuangnya ke Sungai. }\end{array}$ \\
\hline Kepedulian sosial & 9. & $\begin{array}{l}\text { Jaga Masa Depanmu, Katakan Tidak Pada } \\
\text { Narkoba. }\end{array}$ \\
\hline Kepedulian sosial & 10. & $\begin{array}{l}\text { Jangan Anda Jadi korban Berikutnya } \\
\text { Waspadalah }\end{array}$ \\
\hline Kepedulian sosial & 11. & $\begin{array}{l}\text { Kecelakaan Lalu Lintas } \\
\text { Selalu } \\
\text { Didahului Pelanggaran Lalu Lintas }\end{array}$ \\
\hline Kepedulian sosial & 12. & Mas Bro, Kalau Ngantuk Istirahat yaa.. \\
\hline Kepedulian sosial & 13. & $\begin{array}{l}\text { Warning buat Emak-emak! } \\
\text { Antar-jemput Anak Sekolah Naik Motor } \\
\text { "Putra-Putrinya Wajib Pakai Helm" }\end{array}$ \\
\hline Kepedulian sosial & 14. & Awas!Daerah Rawan Kecelakaan \\
\hline Kepedulian sosial & 15. & $\begin{array}{l}\text { Ingin Tahu Mukjizat Al Quran?? } \\
\text { Ayo!!! Baca dengan Arti dan Maknanya. }\end{array}$ \\
\hline Kepedulian sosial & 16. & $\begin{array}{l}\text { Ayo!!! } \\
\text { Budayakan Matikan Tv, Hp, Membaca Kitab } \\
\text { Suci dan Belajar Jam } 18.00 \text { sd 20.00 WIB. }\end{array}$ \\
\hline Kepedulian sosial & 17. & $\begin{array}{l}\text { Dilarang ngebut.. } \\
\text { Penggali kubur sudah pada lebaran }\end{array}$ \\
\hline
\end{tabular}


Data (1) iklan di atas berisi tentang kepedulian sosial untuk saling mengingatkan. Nilai sosial merupakan bentuk dari sebuah sikap dan tindakan yang selalu ingin memberi bantuan pada orang lain, mengingatkan, dan memedulikan keadaan sekitar. Konteksnya adalah mengingatkan para pengguna jalan terutama saat melewati jalan tersebut agar hatihati saat melaju karena banyak sekali tikungan tajam yang dilalui.

Data (2) berupa nilai persaudaraan dan kepedulian sosial yang tumbuh dari ide komunikator untuk dieksplorkan kepada pembaca. Konteks di iklan tersebut membahas salah satu rahasia Allah yaitu ajal, bahwa ajal tidak mengenal waktu, usia, maupun tempat. Jadi selain menganjurkan kepada para pembaca agar secepatnya melaksanakan taubat, Komunikator juga memberitahu bahwa ajal bisa datang kapan saja tanpa diketahui masanya. Oleh sebab itu iklan tersebut mendidik masyarakat yang selalu sibuk dengan pekerjaan dan aktivitas sehari-hari mereka.

Pada data (3) nilai moral berupa nilai kepedulian sosial yang kembali mengingatkan kepada khalayak umum untuk senantiasa menjaga keselamatanmya baik selama kerja maupun setelah kerja. Baris kedua dari iklan tersebut yang berbunyi karena bahaya tak mengenal kata cuti menegaskan bahwa kapanpun bahaya ada di sekeliling kita, bahaya tidak pernah libur atau hilang dari sekeliling kita.

Data (4) nilai moral bentuk kepedulian sosial terhadap masyarakat. Jangan ikuti jejak saya iklan tersebut secara tersirat menyindir para pengguna jalan agar berhati-hati saat mengemudi. Bentuk kepedulian sosial ini dibuktikan oleh komunikator dengan adanya motor rusak yang dinaikkan kemudian ditaruh di atas tulisan tersebut, ditambah lagi dengan gambar tengkorak yang identik dengan kematian.

Nilai moral pada data(5) berupa kepedulian sosial dan kepekaan sosial. Hal ini terbukti di kawasan jalan tersebut terdapat iklan yang memberikan informasi kepada pengemudi bahwa jalan yang dilalui berlobang dan bergelombang. Selain itu, isi dari iklan tersebut juga mengimbau agar hati-hati selama menyusuri jalan tersebut.

Nilai moral yang terkandung dalam iklan layanan masyarakat pada data (6) di atas berupa kepedulian sosial. Keunikan yang terdapat pada iklan tersebut terdapat pada penggunaan bahasa keseharian masyarakat sehingga, pembaca akan diingatkan secara persaudaraan. Iklan yang terdapat di Solo tepatnya di jalan Slamet Riyadi ini dipajang dengan menggunakan bahasa daerah yaitu bahasa Jawa. Apalagi bahasa Jawa yang bertuliskan bersifat memuji pengguna jalan. Seperti pada kalimat seng lanang tambah ganteng dan seng wedok tambah ayu. Kalimat tersebut apabila ditafsirkan dengan makna Jawa yaitu ngalem atau memuji. Mengakibatkan pembaca akan merasa malu apabila mereka tidak membawa helm.

Pesan moral pada iklan layanan masyarakat data (7) di atas adalah bentuk dari kepedulian sosial terhadap pengguna jalan baik sepeda motor, pengemudi mobil, truk, atau bus. Komunikator tetap menambahkan peringatan dan mengimbau agar tetap hati-hati saat melalui jalan tersebut karena sering terjadi kecelakaan. Pesan yang dipajang di jalan tersebut mengimbau para pengemudi agar tetap jaga jarak pada saat rute yang dilalui menanjak. Sekalipun jalan yang dilalui tidak menanjak para pengemudi harus tetap waspada dan jaga jarak, karena kita tidak tahu apa yang nantinya akan terjadi.

Nilai moral pada data (8) berupa kepedulian sosial dan tanggung jawab sosial. Menjaga kebersihan sungai dari sampah dan kotoran lainnya tidak hanya menjadi tugas perorangan, tetapi menjadi tugas bersama antar umat. Beberapa musibah seperti banjir bandang, saluran air tersumbat dan air sungai meluap tidak lain faktornya adalah sampah, limbah dan kotoran-kotoran yang mampu mengakibatkan hal tersebut terjadi. Dengan begitu, pemerintah kota Sragen mengajak masyarakat untuk menjaga sungai agar sungai tetap indah dilihat dan tidak meimbulkan 
bencana, hal ini merupakan tanggung jawab bersama dalam menjaga keindahan kota.

Nilai moral yang yang terdapat pada data (9) berupa kepedulian sosial yang berbunyi anjuran untuk menjaga masa depan anak, masa depan remaja, dan masa depan orang-orang di sekitar kita agar terhindar dari narkoba. Penggunaan obat-obatan terlarang setiap tahunnya mengalami kenaikan jumlahnya dan mengakibatkan para remaja kehilangan masa depannya. Iklan tersebut mengajak masyarakat agar tidak mengonsumsi atau bahkan sekadar mendekati obat-obatan terlarang tersebut.

Pada data (10) nilai moral pada iklan layanan masyarakat di atas adalah bentuk kepedulian sosial yang disampaikan komunikator kepada masyarakat, khususnya bagi pengguna jalan Ngawi. Melalui iklan tersebut, masyarakat diharapkan memerhatikan imbauan-imbauan yang ada.

Pada data (11) nilai moral pada iklan di atas adalah kepedulian sosial yang dilakukan pihak kepolisian Sragen. Tujuan dari memajang iklan di atas tidak lain adalah agar masyarakat mematuhi rambu-rambu lalu lintas yang telah diatur. Sejauh ini, pengguna jalan masih nakal dan cenderung melanggar aturan lalu lintas. Seperti, lampu merah yang seharusnya berhenti tidak berhenti, belok kanan yang seharusnya memberi tanda dengan lampu sen_tidak dilaksanakan.

Pada data (12) nilai moral kepedulian sosial yang tujukan kepada pengguna jalan, utamanya pengendara sepeda motor, bus, trusk dan sejenisnya. Komunikasi bahasa pada iklan di atas sangatlah bersahabat dan terlihat lebih ramah sehingga pembaca yang membaca iklan tersebut akan tersentuh hatinya dan dengan mudah mematuhi imbauan-imbauan yang ada. Salah satu pemicu maraknya kecelakaan lalu lintas yaitu menyetir dalam keadaan sedang mengantuk. Para pengemudi cenderung masa bodoh dan menggampangkan imbauanimbauan yang ada, efeknya kecelakaan sering terjadi akibat pengemudi yang keras kepala.

Pada data (13) nilai moral kepedulian sosial dan kepekaan sosial yang dianjurkan oleh kepolisian Solo kepada para ibu-ibu yang hendak menjemput anaknya di sekolah. Mengenakan helm untuk anak-anak tidak semata-mata agar kena tilang, melainkan lebih pada keselamatan buah hati mereka. Oleh sebab itu, orang tua diminta dengan hormat agar memerhatikan anjuran-anjuran yang diusulkan oleh komunikator terutama dari pihak kepolisian setempat.

Nilai moral yang terkandung pada data (14) yaitu kepedulian sosial. Berharap dengan adanya iklan yang dipajang di jalan tersebut dapat membantu mengurangi angka kecelakaan yang sering terjadi. Sebab jalan yang dilalui seringkali dilewati oleh truk tronton dan truk dengan muatan yang berat lainnya sehingga hal tersebut dapat membahayakan pengguna jalan lainnya apabila tidak hati-hati dalam mengendarai.

Nilai moral pada data (15) kepedulian sosial, pesan yang disampaikan mengingatkan kita kepada Allah karena pesan yang disampaikan mengingatkan manusia agar mempelajari Al Quran untuk mengetahui arti dan maknanya. Pesan tersebut juga bentuk usaha membuka kembali hati bagi orang-orang yang telah lama tertutup agar kembali terbuka dan kembali sadar pada rutinitas yang seringkali dilalaikan, yaitu membaca $\mathrm{Al}$ Quran.

Data (16) mengandung nilai moral kepedulian sosial yang dilakukan oleh SPBU Kabupaten Sragen kepada masyarakat, khususnya untuk pengguna lalu lintas yang sedang mengisi bensin. Iklan tersebut mengajak khalayak untuk kembali pada rutinitas yang telah hilang yaitu mematikan gawai dan televisi untuk sejenak dan mengaji Al Quran sehingga anak akan terbiasa dengan hal baik dan dapat mengatur kegiatan sesuai waktunya.

Data (17) mengandung nilai moral kepedulian sosial. Konteks iklan di atas ditujukan untuk para pemudik karena bertepatan dengan musim mudik hari raya idul fitri. Telah diketahui maraknya kecelakan pada saat mudik tiba, baik pengendara motor maupun mobil. salah satu faktor yang menyebabkan terjadinya kecelakaan adalah 
pengendara yang mengantuk, ngebut, tidak mematuhi lalu lintas, barang bawaan yang terlalu banyak dan lain sebagainya. Oleh sebab itu, iklan tersebut mengingatkan kepada para pemudik untuk senantiasa berhati-hati.

\section{SIMPULAN}

Gaya bahasa yang ditemukan berupa gaya bahasa penegasan yang berjumlah dua puluh data, sindiran berjumlah enam data, data yang mengandung nilai moral kepedulian sosial berjumlah tujuh belas data. Dapat diambil kesimpulan bahwa data terbanyak ialah gaya bahasa jenis ekslamasio yang berjumlah dua puluh data. Mengenai maksud dan tujuan komunikator tidak lain adalah untuk menyadarkan, mengingatkan, dan mengimbau kepada masyarakat tentang suatu hal yang belum diketahui, maupun hal-hal yang sering dilupakan. Komunikator menambahkan informasi dan nasehat serta pengetahuan kepada masyarakat umum untuk diindahkan tidak hanya sekadar dibaca. Gaya bahasa dan nilai moral pada iklan layanan masyarakat, dapat menjadi pengingat dan pelajaran bagi para pengguna lalu lintas dan masyarakat dari iklan yang ditemui.

\section{DAFTAR PUSTAKA}

Annisa. 2018. Hubungan Penguasaan Gaya Bahasa Perbandingan Terhadap Kemampuan Menulis Puisi Siswa Kelas VII SMP Dwi Tunggal Tanjung Morawa Tahun Pembelajaran 2016/2017. Jurnal Pendidikan Bahasa dan Sastra Indonesia, Volume 1, Nomor 1, Mei 2018. Hal 11.

Hasanah, Dian Uswatun dkk. 2019. Analisis Penggunaan Gaya Bahasa Puisi-puisi Karya Fadli Zone. KEMBARA: Jurnal Keilmuan Bahasa, Sastra, dan Pengajarannya Vol. 5, No. 1, April, 2019, hal 21.

Inderasari, Elen dan Ferdian Achsani. 2018. Gaya Bahasa Repetisi dan Perbandingan serta Pesan Moral Pada Lirik Lagu Genre Dangdut Koplo. Jurnal Penelitian
Pendidikan Bahasa dan Sastra Indonesia V4.i2, hal 328.

Mudzakkir Yusuf dan Abdul Mujib. 2010. Ilmu Pendidikan Islam. Jakarta: Kencana.

Mukaromah, dkk. 2017. Iklan Layanan Masyarakat dan Respon Khalayak. Islamic Comunication journal Volume 02, Nomor 02, Juli-Desember 2017 hal 221.

Munir, Saiful dkk. Diksi Dan Majas Dalam Kumpulan Puisi Nyanyian Dalam Kelam Karya Sutikno W.S: Kajian Stilistika. Jurnal Sastra Indonesia 2 (1) (2013). Hal: 3 .

Nasucha, Yakub dkk. 2012. Bahasa Indonesia untuk Penulisan Karya Tulis Ilmiah. Yogyakarta: Media Pustaka.

Neonisa, Didir. 2011. Peran Iklan Layanan Masyarakat dalam Sosialisasi Program

Dalam Sosialisasi Program Busway Oleh Pemprov Dki: Proses Sosialisasi Program Busway. HUMANIORA Vol.2 No.2 Oktober 2011. Hal 1449.

Pujiyanto. 2014. Iklan Layanan Masyarakat. Yogyakarta: CV. Andi Offset.

Ratna, Nyoman Kutha. 2013. Stilistika Kajian Puitika Bahasa, Sastra, dan Budaya. Yogyakarta: Putaka Pelajar.

Salfia, Nining. 2015. Nilai Moral dalam

Novel 5 Cm Karya Donny Dhirgantoro. Jurnal Humanika No. 15, Vol. 3, Desember 2015, hal 7.

Sutopo, H.B. 2002. Metodologi Penelitian Kualitatif. Surakarta: Sebelas Maret University Press.

Tarigan, Henry Guntur. 2013. Pengajaran Gaya Bahasa. Bandung: Angkasa Bandung.

Teeuw. 2015. Sastra dan Ilmu Sastra pengantar Teori Sastra. Jakarta: Pustaka Jaya. 